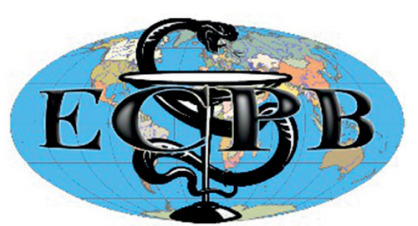

“ЕКСПЕРИМЕНТАЛЬНА ТА КЛІНІЧНА ФІЗІОЛОГІЯ І БІОХІМІЯ” "EXPERIMENTAL AND CLINICAL PHYSIOLOGY AND BIOCHEMISTRY" Науково-практичний журнал/Scientific-practical journal

Наукові статті / Research Articles

ECPB 2019, 3(87): 5-11. https://doi.org/

UDC 618.2+618.3):616.15-07:(546.48+546.81):612.63.02:"44-09"

\title{
Lead, cadmium, copper and zinc content in women's blood during the third trimester of uncomplicated and complicated gestation
}

\author{
M.R GZHEGOTSKYI, N.V. SUKHODOLSKA
}

Danylo Halytsky Lviv National Medical University, Lviv, Ukraine

\section{E-mail: natalia.suhodolska@gmail.com}

In modern realities of adverse effects of ecosystem on human health, WHO experts have proposed a program of research "Human reproduction", whose main task is to study the negative impact of environmental factors on the generative function [1-3]. Under the high technogenic loading conditions, the problem of harmful influence of heavy metals in combination with the imbalance of trace elements on woman's organisms, which lead to a decrease in adaptation reserves with the further development of changes in most systems of the organism, is urgent [4-6].

Recent studies have already identified a correlation between the elevated levels of lead in the blood and the development of threatened abortion and premature birth syndrome [7,8]; excess of lead causes the miscarriage, intrauterine growth restriction, chronic fetal hypoxia, birth defects in newborn babies $[9,10]$. High levels of cadmium in the placenta adversely affect the anthropometric data of the newborn - weight, height, chest circumference [4,11].

Copper plays a role in the mobilization of iron to plasma from the tissue stores and copper deficiency during embryonic and foetal development has been found to cause numerous gross structural and biochemical abnormalities. It has been reported that more than $50 \%$ of human conception fail to implant and of those implanted, approximately $30 \%$ fail to reach term due to copper deficit. Lower plasma copper levels have been found in case of chronic intrauterine hypoxia and fetal hypotrophy, internal organ abnormalities $[7,12]$.

Deficiency of zinc as an essential trace element with wide range of functions including the synthesis of enzymes leads to pregnancy wastage, congenital abnormalities, placental abruption, pregnancy induced hypertension, miscarriage and low birth weight $[13,14]$. Lower plasma zinc concentrations during the pregnancy is associated with preeclampsia, threatened abortion, premature birth syndrome, birth defects, circulatory disorders, the immune response impairments, and disorders of psychological development $[15,16]$.

In this regard, it is relevant to study the effects of toxic and trace elements on pregnancy through the investigation of their content in women's blood during uncomplicated and complicated gestation, with further elaboration of methodological algorithms for physiological monitoring of pregnancy for the timely implementation of preventive measures.

The aim of this research was to evaluate lead, cadmium, copper and zinc content in women's blood during III trimester of pregnancy and to assess the correlation between their levels and gestational complications. 
Materials and methods. The content of lead, cadmium, copper and zinc in the blood of 115 pregnant women during third trimester of uncomplicated and complicated gestation was investigated. These women were under medical supervision in the prenatal first city community clinic and maternity hospitals in Lviv. The following criteria were chosen: homogeneity of social status, absence of physical, genetic and oncological diseases, a burdened obstetric and gynecological history.

The investigation of metal levels in the blood of 45 women with physiological course of pregnancy and 70 women with gestation complicated by threatened abortion (40.0\%), anemia (31.4\%) and gestational pyelonephritis (28.6\%) was carried out. The course of pregnancy was analyzed by processing primary statistical documents - an individual map of a pregnant and parturient woman (form 111/o).

The inversion voltammetry method was applied for determination of metal concentrations. The preparation of blood samples was conducted in the Central Research Laboratory and Laboratory of industrial toxicology of Danylo Halytsky Lviv National Medical University. Measurements were carried out using the voltammetry analyzer AVA-2 in the Sanitary Epidemiological Station of Lviv Railway.

The statistical analysis was performed by using the program «Statistics v.6.0" and included the calculation of mean values, their standard errors, the probability of difference by using Mann-Whitney method, the correlation analysis by using Pearson's method and binary logistic regression.

Results and discussion. The average content of lead in women's blood during third trimester of complicated pregnancy was relatively higher $(p<0.01)$ than in women with the uncomplicated course of gestation $(0.058 \pm 0.005 \mathrm{mg} / \mathrm{L})$. The highest concentration of metal $-0.243 \pm 0.045 \mathrm{mg} / \mathrm{L}$ was recorded in the blood of women with threatened miscarriage (Fig. 1). It was found slightly lower lead level in women with anemia $(0.223 \pm 0.032 \mathrm{mg} / \mathrm{L})$, which was 3.8 times higher than in uncomplicated pregnancy. Lead content in pyelonephritis was equal to $0.182 \pm 0.031 \mathrm{mg} / \mathrm{L}$ that 3.1 times exceeded the index in women without complications.

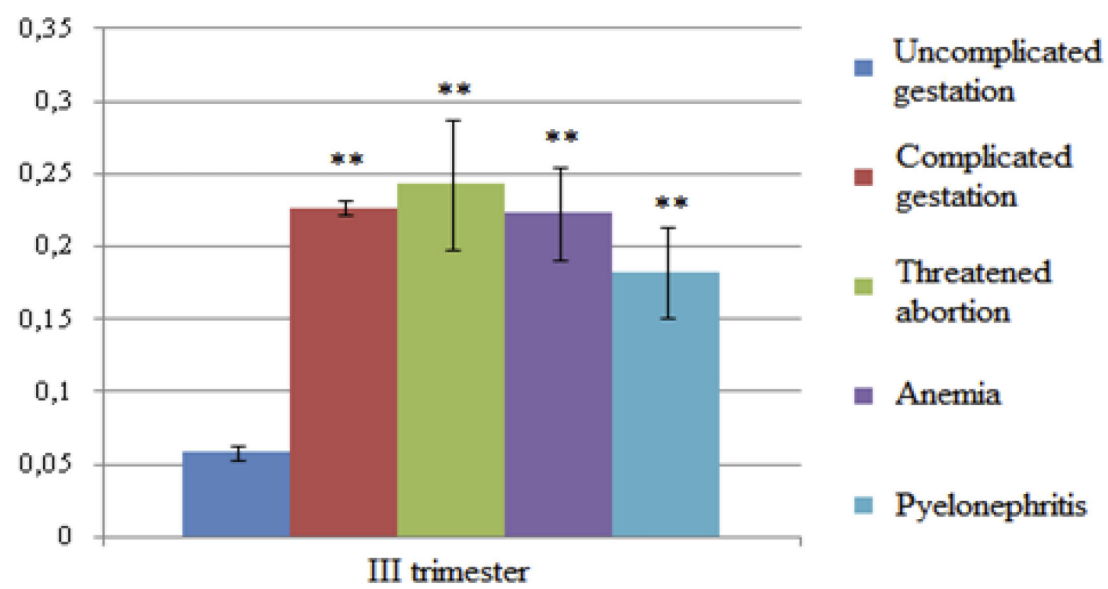

Fig. 1. Content of lead in the women's blood (mg/L)

Note: $* *-p<0.01$ as compared with uncomplicated pregnancy

The level of cadmium in the third trimester of pregnancy was significantly $(p<0.01)$ different in the groups with uncomplicated and complicated pregnancy (Fig. 2). The average metal content during gestational complications was relatively 3.8 times higher $(p<0.01)$ than in women with physiological pregnancy $(0.0038 \pm 0.0004 \mathrm{mg} / \mathrm{L})$. The highest concentration of cadmium $0.0160 \pm 0.0027 \mathrm{mg} / \mathrm{L}$ was recorded in pyelonephritis that exceeded 4.2 times 
the index in uncomplicated gestation. The lowest level was found in women with anemia $-0.0113 \pm 0.0019 \mathrm{mg} / \mathrm{L}$.

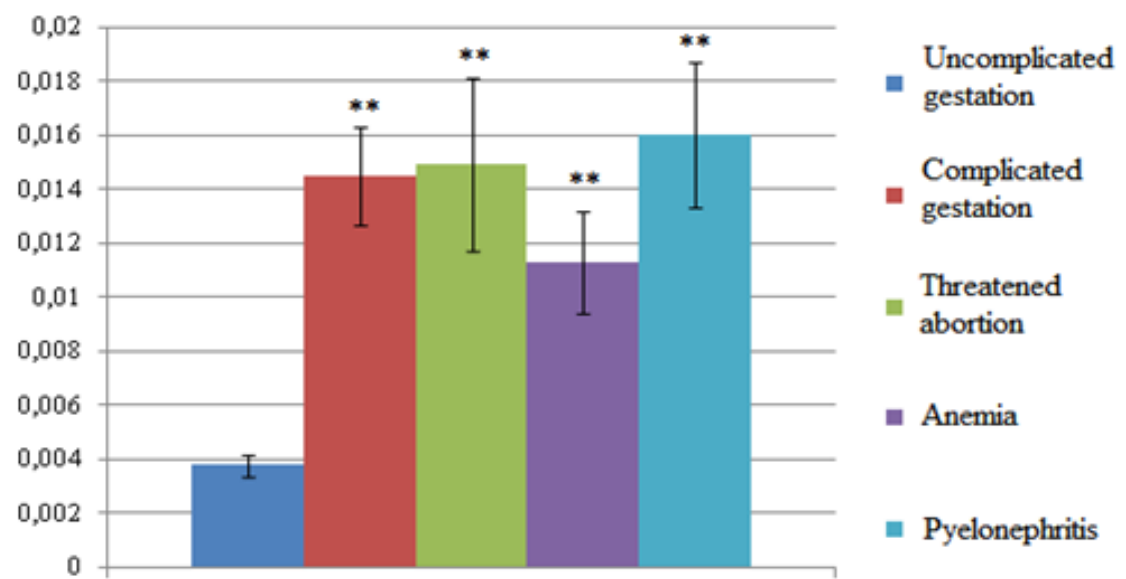

III trimester

Fig. 2. Content of cadmium in the women's blood $(\mathrm{mg} / \mathrm{L})$

Note: $* *-p<0.01$ as compared with uncomplicated pregnancy

It was established that the average copper content in women's blood with uncomplicated gestation was equal to $3.018 \pm 0.052 \mathrm{mg} / \mathrm{L}$ that almost twice exceeded the index in women with gestational complications. The lowest copper content was found during anemia $-1.437 \pm 0.127 \mathrm{mg} / \mathrm{L}$ (Fig. 3). Women with threatened abortion $(1.656 \pm 0.123 \mathrm{mg} / \mathrm{L})$ and pyelonephritis $(1.816 \pm 0.175 \mathrm{mg} / \mathrm{L})$ had respectively 1.8 and 1.6 times lower concentrations of metal than women with physiological course of gestation.

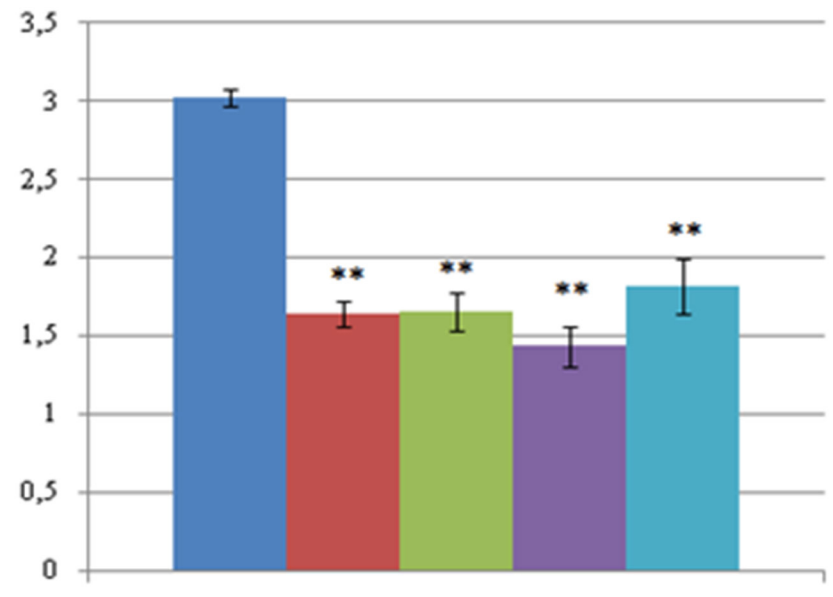

III trimester

\section{- Uncomplicated gestation}

- Complicated gestation

Threatened abortion

Anemia

Pyelonephritis

Fig. 3. Content of copper in the women's blood (mg/L)

Note: $* *-p<0.01$ as compared with uncomplicated pregnancy

The average level of zinc in women's blood during third trimester of complicated gestation was significantly $1.3-1.5$ times $(p<0.01)$ lower than in women with physiological pregnancy $(5.351 \pm 0.220 \mathrm{mg} / \mathrm{L})$. The lowest content of element was found during threatened miscarriage $-3.639 \pm 0.271 \mathrm{mg} / \mathrm{L}$ (Fig. 4). Women with anemia and pyelonephritis had $3.964 \pm 0.307 \mathrm{mg} / \mathrm{L}$ and $3.857 \pm 0.286 \mathrm{mg} / \mathrm{L}$ respectively.

The correlation between the content of toxic and essential elements in the blood of pregnant women was evaluated by correlation analysis. It was found 
that in the third trimester of physiological gestation, the lead content was inversely correlated with the level of copper $(r=-0.38 ; p<0.05)$ and directly depended on cadmium concentration $(\mathrm{r}=0.45 ; \mathrm{p}<0.05)$; however, no association between lead and zinc content was found.

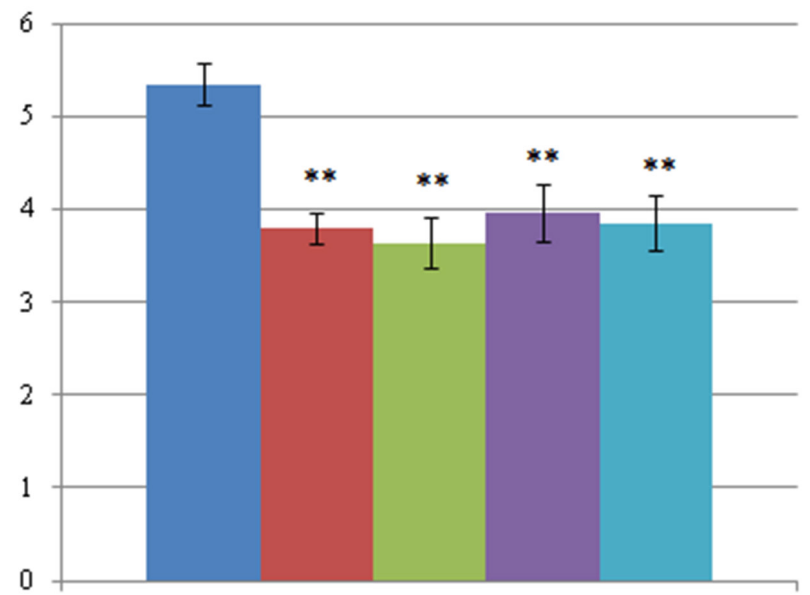

Uncomplicated gestation

. Complicated gestation

- Threatened abortion

Anemia

Pyelonephritis

III trimester

Fig. 4. Content of zinc in the women's blood $(\mathrm{mg} / \mathrm{L})$

Note: $* *-p<0.01$ as compared with uncomplicated pregnancy

The lowest levels of lead (up to $0.08 \mathrm{mg} / \mathrm{L}$ ) were combined with high copper concentrations (up to $1.5 \mathrm{mg} / \mathrm{L}$ ) regardless to the cadmium content. At the same time, the high levels of lead (up to $0.56 \mathrm{mg} / \mathrm{L}$ ) were observed in the case of the combination of increased cadmium content (over $0.005 \mathrm{mg} / \mathrm{L}$ ) and the decreased copper concentrations (up to $0.8 \mathrm{mg} / \mathrm{L}$ ) (Fig. 5).

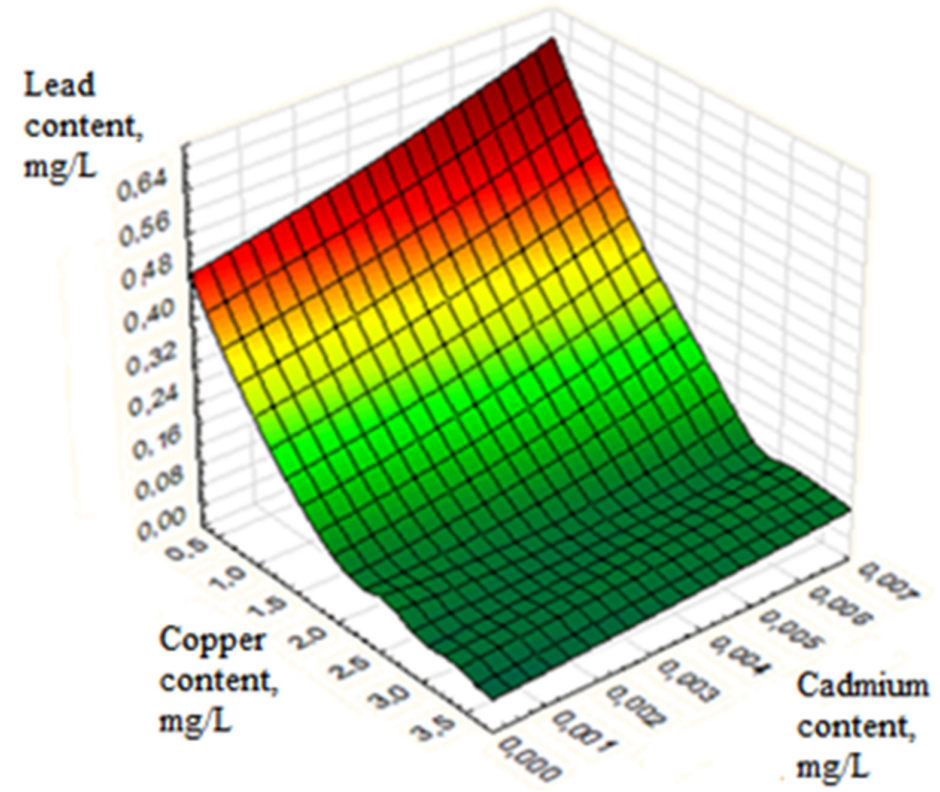

Fig. 5. Correlation between lead, copper and cadmium content in the blood of women during the third trimester of uncomplicated gestation

The correlation analysis between the content of toxic and essential elements in the third trimester of complicated gestation was showed a significant $(p<0.05)$ 
direct connection between levels of trace elements $(r=0.43 ; p<0.05)$. The elevation of lead content was combined with the increased cadmium level $(r=0.41$; $\mathrm{p}<0.05$ ), while the decreasing of lead concentration - with the increased zinc concentration $(r=-0.43 ; \mathrm{p}<0.05)$.

The direct correlation between cadmium and lead levels $(r=0.56 ; p<0.05)$ was observed in women with threatened miscarriage. The elevation of zinc content in women with anemia was discovered in the case of the increased copper concentration $(r=0.77 ; \mathrm{p}<0.05)$ and the decreased cadmium level $(r=-$ $0.58 ; \mathrm{p}<0.05)$, the increase in copper concentration was found with decreased cadmium level $(r=-0.86 ; p<0.05)$. The increased lead content with decreased of zinc concentration $(r=-0.67 ; p<0.05)$ was observed in women with pyelonephritis.

Taking into account the significant differences between the content of toxic and trace elements in women's blood during physiological and pathological pregnancy, the relationships between them and gestational complications using the pair correlation have been analyzed thoroughly (Fig. 6).

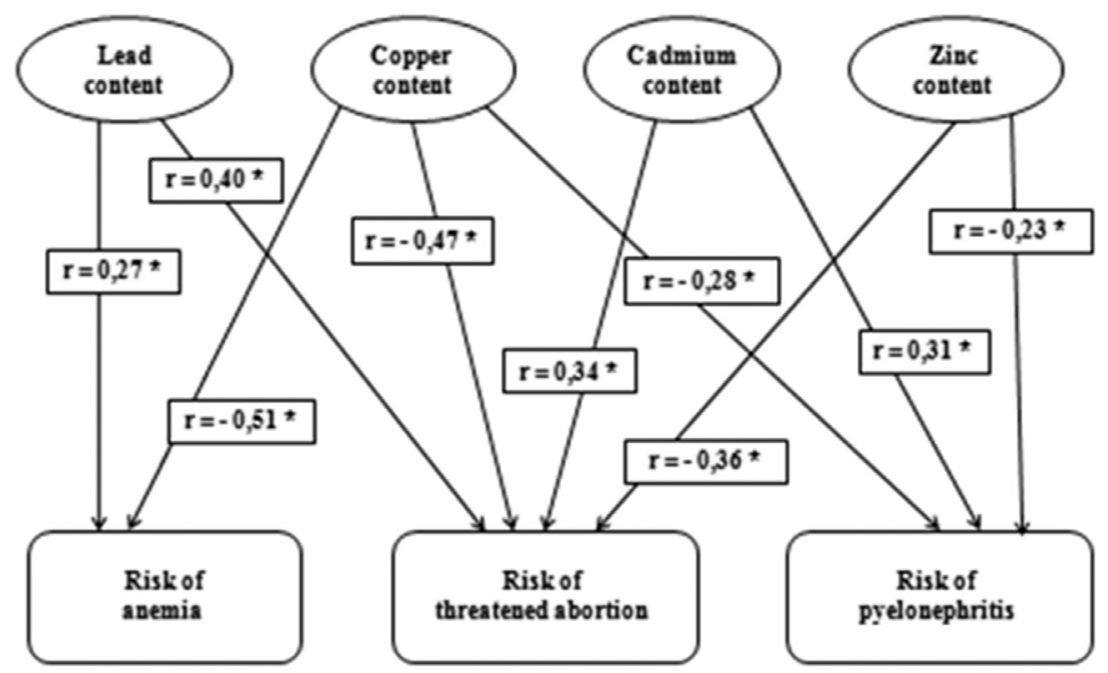

Fig. 6. Correlation coefficients between the metals blood content

and the risk of gestational complications in the third trimester of pregnancy. ${ }^{*}-\mathrm{p}<0.05$

It was found that the risk of miscarriage is associated with high levels of lead $(r=0.40 ; p<0.05)$ and cadmium $(r=0.34 ; p<0.05)$, as well as with low copper contents $(r=-0.47 ; p<0.05)$ and zinc $(r=-0.36 ; p<0.05)$. The probability of anemia in the third trimester of pregnancy is elevated with increased lead levels $(\mathrm{r}=0.27 ; \mathrm{p}<0.05)$ and decreased copper content $(\mathrm{r}=-0.51 ; \mathrm{p}<0.05)$. The risk of pyelonephritis was combined with high concentrations of cadmium $(r=0.31$; $p<0.05)$ and low levels of copper $(r=-0.28 ; p<0.05)$ and zinc $(r=-0.23 ; p<0.05)$.

Conclusion. Comparative analysis of investigated elements content in the women's blood during the third trimester of pregnancy has revealed 3.1-4.2 times higher levels of toxic metals and 1.3-2.1 times lower concentrations of trace elements in all groups of women with complicated pregnancy. The highest lead levels and the lowest zinc content were found in women with the threatened miscarriage, the highest level of cadmium - in women with pyelonephritis and the lowest copper content - during anemia.

The inverse correlation between lead and copper content as well as direct connection between lead and cadmium levels were found in the third trimester of uncomplicated gestation. The elevation of lead level with the increasing of cadmium content was observed in women with threatened miscarriage; the increased zinc concentration was correlated with higher copper content and lower cadmium concentration during anemia; the elevation of lead content with decreased of zinc level was found in pyelonephritis. 
It was found the provoking effect of cadmium and lead as well as preventive effect copper and zinc on the appearance of gestational complications. The risk of threatened abortion was combined with high levels of both toxic metals and lower content of trace element, the risk of anemia was correlated with a low concentration of copper and high content of lead, the probability of pyelonephritis development was increased with high levels of cadmium and low in copper and zinc content.

\section{REFERENCES (ПОСИЛАННЯ)}

1. Авраленко НВ, Барковский ДЕ. Аспекты репродуктивного здоровья населения Украины. Запорожский медицинский журнал. 2010;12(3):71-3 (Avramenko NV, Barkovskyi DY. Reproductive health aspects of the Ukraine population. Zaporozhye Medical Journal. 2010;12(3):71-3).

2. Білецька ЕM, Плачков СФ, Антонова ОВ, Онул НМ, Головкова ТА, Чуб ЛЕ та ін. Техногенне забруднення атмосферного повітря як фактор впливу на антропометричні показники новонароджених. Довкілля та здоров'я. 2010;3(54):60-6 (Biletska EM, Plachkov SF, Antonova OV, Onul NM, Golovkova TA, Chub LE et al. Technogenic pollution of atmocheric air as factor of influence on the antropometric indexes of new-born. Environ. and Health. 2010;3(54):60-6).

3. Онул HM. Гігієнічна діагностика стану репродуктивного здоров'я населення промислового регіону (фактори ризику, профрілактика): авторед. дис. на здобуття наук. ступеня док. мед. наук: спец. 14.02.01 «Гігіена та професійна патологія». Київ; 2015. 39 с. (Onul NM, Hygienic diagnostics of reproductive health of population of the industrial region (risk factors, prevention): avtoref. dys. na zdobuttia nauk. stupenia dok. med. nauk: spets. 14.02.01 "Hihiiena ta profesiina patolohiia», Kyiv; 2015. 39 p.).

4. Ikeh-Tawari EP, Anetor JI. Charles-Davies MA. Cadmium level in pregnancy, influence on neonatal birth weight and possible amelioration by some essential trace elements. Toxicol. Int. 2013;20(1):108-12. doi:10.4103/0971-6580.111558.

5. Білецька EM, Онул HM, Головкова TA. Вміст металів у біосубстратах вагітних промислового регіону. Вісник проблем біології і медицини. 2015;2(4):65-8 (Biletska EN, Onul NM, Golovkova TA. Metal content in biosubstrates of pregnant women of the industrial region. Bulletin of Problems of Biology and Medicine. 2015;2(4):65-8).

6. Zheng G, Zhong H, Guo Z, Wu Z, Zhang H, Wang C. et al. Levels of heavy metals and trace elements in umbilical cord blood and the risk of adverse pregnancy outcomes: a populationbased study. Biological Trace Elements Resources 2014;160(3):437-44. URL: doi:10.1007/ s12011-014-0057-x.

7. Вениківський БМ, Осадчук СВ. Вміст важких металів у біологічних субстратах системи "мати - плацента - плід" за синдрому затримки розвитку плоду. Ліки України. 2010;3(12):38-41 (Ventskivsky BM, Osadchuk SV. Heavy metal content in biological substrates of "mother-placenta-fetus" with the syndrome of fetal growth retardation. Drugs of Ukraine. 2010;3(12):38-41).

8. Гюегоцкий $M P$, Суходольская НВ. Влияние меди, цинка, кадмия и свинца на вероятность развития угрозы прерывания беременности у женщин. Репродуктивное здоровье. Восточная Европа. 2014;1:43-9 (Gzhegotsky MR, Sukhodolska NV. Influence of cooper, zinc, cadmium and lead on arising threat of miscarriage in women Reprod. health. Eastern Europe. 2014;1:43-9).

9. Xie X, Ding G, Cui C, Chen L, Gao Y, Zhou Y. et al. The effects of low-level prenatal lead exposure on birth outcomes. Environ. Pollut. 2013;175:30-4. doi: 10.1016/j.envpol.2012.12.013.

10. Трахтенберг IM, Луговський СП, Длитруха НМ, Лубянова ІП., Талакін ЮМ, Харченко ТД. Свинцева небезпека в Україні: сучасні реалії, проблеми та шляхи вирішення. Науковий журнал MO3 України. 2013;3:50-60 (Trachtenberg IM, Lugovskoi SP, Dmitruha NM, Lubianova IP, Talakin YM, Kharchenko TD. Lead hazard in Ukraine: current realities, problems and solutions. Sci. J. Ministry of health of Ukraine. 2016;3:50-60).

11. Guo Y, Huo X, Li Y, Wu K, Liu J, Huang J et al. Monitoring of lead, cadmium, chromium and nickel in placenta from an e-waste recycling town in China. Scientific Total Environment. 2010;408(16):3113-7. URL: doi:10.1016/ j.scitotenv. 2010.04.018.

12. Ugwuja EI, Akubugwo EI, Ibiam UA, Obodoa O, Ugwu NC. Plasma copper and zinc among pregnant women in Abakaliki, Southeastern Nigeria. Internet J. Nutrit. Wellness. 2010;10(1):75-81. doi: 10.5580/b7d.

13. Vukelic J, Kapamadzija A, Petrovic D, Grujic Z, Novakov-Mikic A, Kopitovic Vet al. Variations of serum copper values in pregnancy. Srpski Arhiv Celokupno Lekarstvo. 2012;140(1-2):42-6.

14. Rumbold A, Duley L, Crowther CA, Haslam RR. Antioxidants for preventing pre-eclampsia. Cochrane Datab. System. Rev. 2008;1:141-52. doi: 10.1002/14651858.CD004227.pub3.

15. Wang $H$, Yong-Fang $H$, Jia-Hu H, Yuan-Hua C, Pu-Yu S, Ying W et al. Maternal zinc deficiency during pregnancy elevates the risks of fetal growth restriction: a population-based birth cohort study. Scientific Reports. 2015;5:11262. URL: doi:10.1038/srep11262. 
16. Karimi A, Bagheri S, Nematy $M$, Saeidi $M$. Zinc deficiency in pregnancy and fetalneonatal outcomes and impact of the supplements on pregnancy outcomes. IJN. 2012;3:77-83. URL: doi: 10.22038/IJN.2012.270.

\title{
RESEARCH ARTICLE
}

Стаття надійшла до редколегії 06.09.2019

\section{Lead, cadmium, copper and zinc content in women's blood during the third trimester of uncomplicated and complicated gestation}

\author{
M.R. GZHEGOTSKYI, N.V. SUKHODOLSKA \\ Danylo Halytsky Lviv National Medical University, Lviv, Ukraine
}

\section{E-mail: natalia.suhodolska@gmail.com}

Introduction. Reproductive health care is one of the priority problems in modern ecological situation. Environmental pollution by heavy metals and imbalance of trace elements lead to a decrease in adaptation reserves with the further development of changes in most systems of the organism. In this regard, the research of the heavy metals and trace elements effects on pregnancy by studying their content in women's blood during uncomplicated and complicated gestation is an important issue.

The purpose of this study was to assess lead, cadmium, copper and zinc levels in women's blood during the third trimester of gestation and to analyze the correlation between their content and gestational complications.

Materials and methods. Investigation of lead, cadmium, copper and zinc levels in the blood of 45 women with uncomplicated pregnancy and 70 women with gestation complicated by anemia (31.4\%), threatened abortion (40.0 \%) and gestational pyelonephritis (28.6 \%) was carried out. The indication of metals was evaluated by the inversion voltammetry method.

The following criteria were chosen: the third trimester of pregnancy, the homogeneity of social status, the absence of physical, genetic and oncological diseases, burdened obstetric and gynecological history. The course of pregnancy was analyzed by processing primary statistic documents - individual case records of pregnant and parturient women (form 111/o).

Results. The average level of lead and cadmium in women's blood during third trimester of complicated pregnancy were relatively higher $(p<0.01)$ than in women with the uncomplicated course of gestation, while the content of trace elements was significantly lower.

The highest content of lead and cadmium were recorded in the blood of women with threatened miscarriage and pyelonephritis, which was 3.9 and 4.2 times higher $(p<0.01)$ than in uncomplicated pregnancy. Lead level in women with anemia and pyelonephritis exceeded the index in physiological gestation by 3.8 and 3.1 times $(\mathrm{p}<0.01)$ respectively. Pregnant women with anemia and threatened miscarriage had respectively 3.0 and 3.9 times higher cadmium level $(p<0.01)$ than healthy ones.

The average copper and zinc content during the third trimester of gestation was significantly in 1.3-1.8 times $(\mathrm{p}<0.01)$ lower compared with uncomplicated pregnancy. The lowest levels of copper were found in the blood of pregnant women with anemia and the lowest zinc content during threatened miscarriage.

The lowest lead content (up to $0.08 \mathrm{mg} / \mathrm{L}$ ) was combined with high (over $1.5 \mathrm{mg} / \mathrm{L}$ ) copper concentration and did not depend on cadmium concentration in women. At the same time, high level of lead (over $0.56 \mathrm{mg} / \mathrm{L}$ ) was observed in the case of increased cadmium content (over 0.005 $\mathrm{mg} / \mathrm{L}$ ) and decreased copper level (up to $0.08 \mathrm{mg} / \mathrm{L}$ ).

It was shown that combined effects of microelements such as cadmium and lead had provocative action on arising risk of gestational complications, whereas cooper and zinc had preventive action.

In the third trimester of gestation, the development of threatened abortion was combined with high levels of lead and cadmium and low levels of zinc and copper, and the risk of anemia was correlated with a low concentration of copper and high content of lead in the blood of pregnant women and. At the same time increases the risk of pyelonephritis with high levels of cadmium and low in copper and zinc in the blood of pregnant women.

Thus, adverse effects of elevated levels of lead and cadmium, low levels of copper and zinc on the clinical course of pregnancy were found.

Key words: third trimester of gestation, lead, cadmium, copper, zinc. 